\title{
A two-decade record of variations in suspended sediment in the Warta River, a lowland river in western Poland
}

\author{
Katarzyna SKOLASIŃSKA ${ }^{1, *}$, Bogumił NOWAK ${ }^{2}$ and Katarzyna BRADTKE ${ }^{3}$ \\ 1 Adam Mickiewicz University in Poznań, Institute of Geology, Bogumiła Krygowskiego 12, 61-680 Poznań, Poland \\ 2 Institute of Meteorology and Water Management - National Research Institute, Podleśna 61, 01-673 Warszawa, Poland \\ 3 University of Gdańsk, Institute of Oceanography, Al. Marszałka Piłsudskiego 46, 81-378 Gdynia, Poland
}

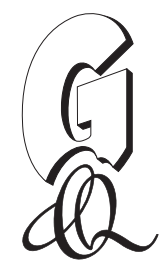

Skolasińska, K., Nowak, B., Bradtke, K., 2020. A two-decade record of variations in suspended sediment in the Warta River, a lowland river in western Poland. Geological Quarterly, 64 (4): 1048-1060, doi: 10.7306/gq.1569

\begin{abstract}
Fluctuations in suspended sediment concentration (SSC) has been investigated in the Warta River (western Poland), based on data obtained for the period 1961-1980 from three gauge stations located in upstream, middle-stream and downstream areas. Over the two decades, the SSC values demonstrated wide fluctuations and an overall increase at each gauge station. No significant correlation was generally observed between SSC and discharge but high SSC was found to follow low discharge and increasing temperature during the summer seasons in some years. Measurements of SSC and discharge were used to estimate total annual suspended sediment load (SSL). SSL values were found to increase downstream along with an increase in discharge. SSC decreases along the river course. However, when it comes to changes over time, SSL variability was mainly determined by SSC changes. The maximum SSC values were primarily caused by anthropogenic factors: the disposal of mine wastewater upstream, river training works, increased urbanisation and the intensification of sewage disposal. Where the river catchment has been greatly affected by anthropogenic factors, a denudation index calculated solely based on SSC and discharge does not appear to reflect the actual denudation rate, and must be treated with caution.
\end{abstract}

Key words: suspended sediment concentration, suspended load, long-term record, anthropogenic impact, lowland river, Warta River.

\section{INTRODUCTION}

Suspended sediment is an inherent element of all river systems, constituting the main load transported by the rivers (Walling and Fang, 2003). Its quantity and quality depends on a range of interrelated meteorological (precipitation, air temperature, wind), hydrological (flow rate, water temperature, ice-related phenomena, tributaries) and geomorphological and geological factors (geology of the river catchment, morphology, stream gradient). A particularly important role is played by human activity, more specifically, the type of land use (forestry, agricultural, industrial, residential) and the modifications to the catchment landscape (hydrotechnical constructions, reservoirs, mines, the transport network construction and road-surface erosion). Research has found that an increase in the amount of transported suspended particles is generally influenced by factors leading to soil erosion in the catchment area, such as climate and the type of land cover (e.g., Walling and Webb, 1996; Sinha et al., 2020; Szalińska et al., 2020). A close look at this question shows that despite decades of research,

\footnotetext{
* Corresponding author, e-mail: katskol@amu.edu.pl Received: May 19, 2020; accepted: September 24, 2020; first published online: November 17, 2020
}

the precise factors influencing how sediment flux varies in rivers, and which interconnections are significant, remain unclear (Vercruysse et al., 2017; Peng et al., 2020).

Studies of suspended sediment transport in rivers are complicated because (Vercruysse et al., 2017; Skolasińska and Nowak, 2018; Peng et al., 2020):

- the complexity of the natural factors determining the amount of suspended sediment in rivers, as well as their interactions with anthropogenic factors;

- the relatively low frequency of SSC sampling, because the samples are usually manually collected for further laboratory analyses;

- the assessment of total SSC is based on measurements of both mineral and organic particles of different origins, which often fluctuate independently during different periods of the hydrological year.

A wide-ranging hydrological monitoring programme of Polish rivers was conducted during 1951-1990 by the State Meteorological and Hydrological Service (currently the Institute of Meteorology and Water Management - National Research Institute, IMGW-PIB). Its findings regarding long-term suspended sediment transport in the Vistula River, the longest river in Poland, have been published (Łajczak, 1999, 2003). An attempt was also made to assess the intensity of denudation processes across Poland using SSC measurements (Brański and Banasik, 1996). A further study by Skolasińska and Nowak (2018) of SSC levels in the Warta River at the upstream gauge 
station in Sieradz during 1961-1980 found maximum SSC levels to be associated with anthropogenic factors, such as the disposal of the wastewater from a lignite open-pit mine and numerous river training works. More importantly, SSC was not found to be directly proportional to discharge levels. Among the natural factors, seasonal changes in water temperature may indirectly cause substantial changes in suspended sediment concentration. In winter, when the river is frozen, the rapid increase in SSC is probably the result of strong erosion of the riverbed and transport of an exceptionally large amount of suspended material. The SSC can also increase rapidly when the ice cover breaks, and subsequent movement of ice floes lead to erosion of the river banks. During the summer, when the water temperature is $\sim 20^{\circ} \mathrm{C}$, increases in SSC may be associated with blooms of algae in the water. Spatial and temporal trends of suspended sediment transport remain open for examination: it is widely recognized that no single factor dominates SSC in rivers, but rather there are many interrelated factors which require further study (see Siakeua et al., 2004; Walling, 2008; Kijowska-Strugała, 2015; Vercuysse et al., 2017). The uncertainty associated with SSC assessment can only be reduced by large-scale evaluation of data sets obtained from long-term observations (Walling and Webb, 1981; Parker, 1988; Olive and Rieger, 1992; Nelson and Booth, 2002).

The main focus of this study is a detailed analysis of SSC measurements taken continuously over the course of two decades, from 1961 to 1980 , in the Warta River catchment; the data was acquired from three gauge stations located in upper(Sieradz), middle- (Poznań) and downstream (Gorzów Wielkopolski) sections. As no detailed studies of SSC have been made in Polish rivers since 1990, only sporadic data are available from this period. The present study analyses the existing data to identify changes in SSC during this period with the aim of identifying:

- potential long-term trends at all stations;

- major factors controlling the maximum SSC values;

- how the suspended sediment load changes over the course of the river.

Since no correlation between SSC and discharge was identified in previous studies (Skolasińska and Nowak, 2018), this issue is addressed in the present study.

\section{STUDY AREA}

The Warta River is the third-longest river in Poland $(808 \mathrm{~km})$, and is also a right-bank tributary of the Oder River, itself the second-longest river in the country (Fig. 1). The Warta drains an area of $54,500 \mathrm{~km}^{2}$, accounting for $17.4 \%$ of the area of Poland. Its source lies at an altitude of $379.2 \mathrm{~m}$ a.s.l. near Zawiercie. The Warta joins the Oder at Kostrzyn, where the water table reaches an elevation of $\sim 12 \mathrm{~m}$ a.s.l. The Warta is a lowland meandering river with a mean gradient of $0.46 \%$.

Like most of the rivers of the Polish Lowland that formed during the Late Pleistocene, the Warta River catchment is elongated, stretching from SE to NW (Fig. 1), being determined by postglacial relief and the northern inclination of the terrain (Falkowski, 1975; Kozarski and Rotnicki, 1978). In its upstream part, the Warta flows in a relatively narrow valley through the Kraków-Czestochowa Upland (consisting mostly of Jurassic limestone) up to its northern rim, near Sieradz. It is characterized here by numerous gorges with typical incised meanders, and then evolves into a classical meandering river in its lowland part. The middle- and downstream sections are characterized by moraine hills composed of Pleistocene glacial tills and fluvio- glacial deposits underlain by clayey deposits of Miocene age (Bartkowski, 1957; Kozarski, 1991). The river valley is filled with gravelly, sandy and muddy Holocene deposits, together with organic-rich deposits, mainly peats and floodplain soils.

Land use in the catchment area is dominated by farmland, especially in the central and southern parts of the region (Piechowiak, 2007). Second in importance are forests, which mainly occur in the northwestern part of the catchment area. Three cities with a population of more than 100,000 are located along the river course (Poznań, Częstochowa and Gorzów Wlkp.) and 22 cities with a total population of 1,280,000 (Ptak et al., 2019).

The Warta and its tributaries are classified as temperate hydrological regimes (Dynowska, 1972), with a dominant early spring high-water stage caused by the melting of snow cover and frozen ground. Summer high-water stages triggered by heavy rainfall also take place; although these can be higher than the spring stages, they occur irregularly and are of lesser importance. High-water stages typically occur from February to May, whereas low-water stages are observed from June to September, unless a rainfall-triggered high-water stage occurs. In recent years, however, this has changed with the influence of global warming (Ptak et al., 2019).

The mean annual precipitation in the Warta catchment basin, based on data from 1951 to 1980 , is $561 \mathrm{~mm}$ (Górski et al., 2019), but the amount of precipitation in individual years is very variable and the difference between dry and wet years can be up to $400 \mathrm{~mm}$ (Piechowiak, 2007).

Mean water temperature $(T)$ of the Warta shows low variability along the river course, i.e. ranging from 9.5 to $10.3^{\circ} \mathrm{C}$, and cycling from $<2^{\circ} \mathrm{C}$ in January to $>20^{\circ} \mathrm{C}$ in July (Ptak et al., 2019); however, mean $T$ was found to increase by $0.096-0.281^{\circ} \mathrm{C}$ per decade during the study period. In recent years there has been a significant shortening of times of freezing on the river (Nowak et al., 2019), while increasingly frequent periods of low water stages and droughts have been recorded during summer periods. Changes in the thermal regime also affect biotic conditions and water quality (Mądrecka and SzelagWasielewska, 2017).

Like most Polish rivers, the Warta has been subjected to many training works. At the beginning of the 19th century, construction began on levees on the natural banks of the middle and downstream parts of the river (Kaniecki, 2004, 2013). During this period, the riverbed was partly straightened and deepened. As a result of the work, the Warta evolved from an anastomosing river with characteristic multiple interconnected channels into a meandering river narrowed by the constructed levees (Forysiak, 2010; Kaniecki, 2013; Goraj, 2015). The river training works continued until the 1970s, when the existing levee structures were developed, in addition, new bridges were built and old ones modernized (Kaniecki, 2013).

Among the anthropogenic impacts, the opening of the Poland's largest lignite mine at Bełchatów (Fig. 1) played an important role in the upper reaches of the river. The mine water drainage system and discharge of the mine water to the local rivers caused a very large impact on the environment, including on river flow and on concentrations of suspended sediment (Wachowiak, 1998; Pierzchała, 2010).

\section{MATERIALS AND METHODS}

This study is based on a detailed analysis of archival materials published in "Rocznik Hydrologiczny wód powierzchniowych". The data were collected from three gauge stations on 


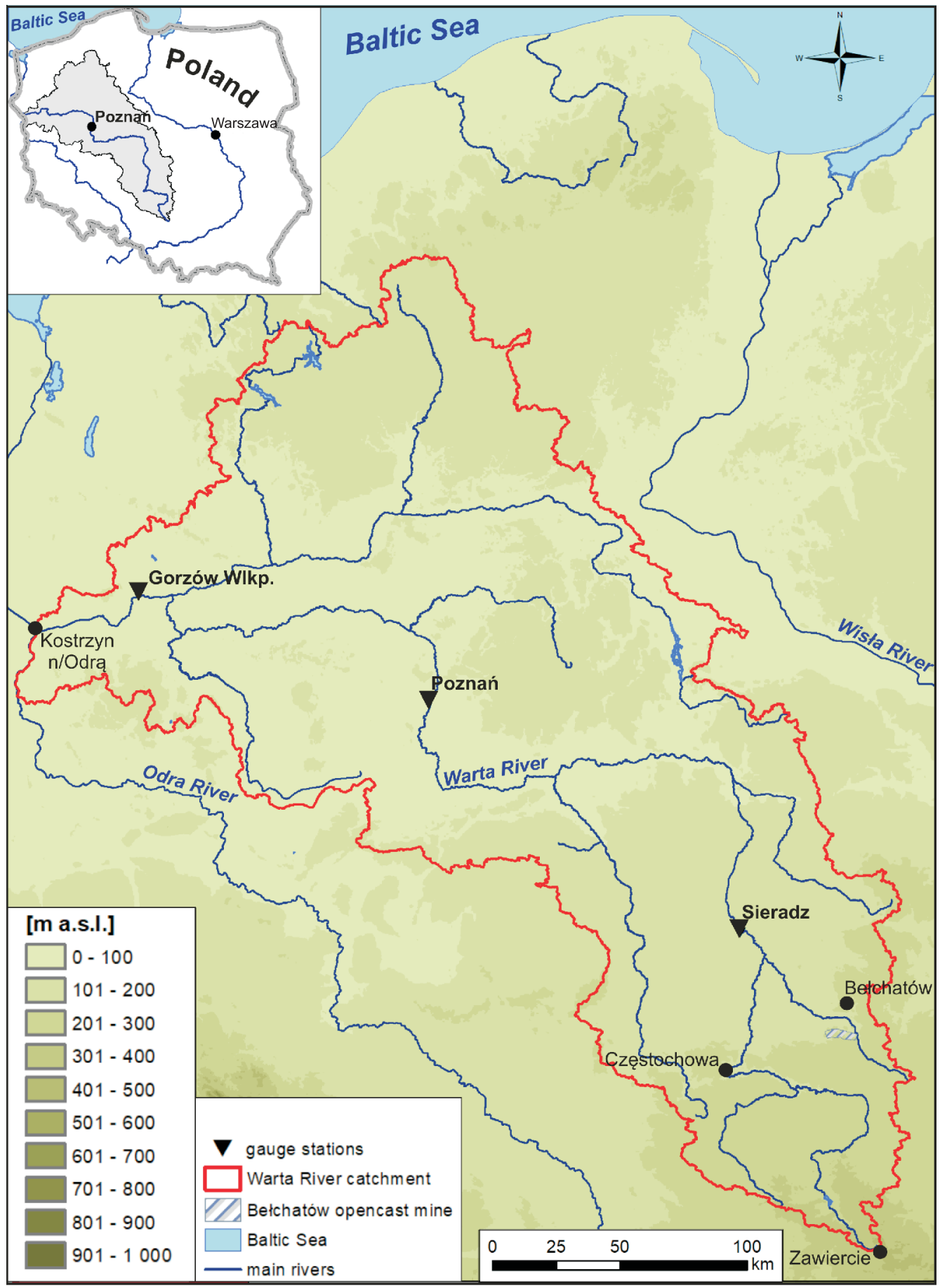

Fig. 1. Location of the study area with three gauge stations on a hypsometry map of the Warta River catchment

the Warta River, located 521, 242 and $56 \mathrm{~km}$ away from the river mouth in the cities of Sieradz, Poznań and Gorzów Wielkopolski, respectively (Fig. 1), these stations therefore being referred to below as Sieradz, Poznań and Gorzów Wlkp. The period chosen covers the most comprehensive SSC measurement record. In total, 10,604 measurements were taken at all three gauge stations over the two decades (Appendix $1^{*}$ ), with each hydrological year beginning on November 1 and ending on October 31.

The dataset analysed includes the following variables: discharge $\left(\mathrm{m}^{3} \cdot \mathrm{s}^{-1}\right)$, water temperature $\left({ }^{\circ} \mathrm{C}\right)$ and SSC $\left(\mathrm{g} \cdot \mathrm{m}^{-3}\right)$. The discharge values provided in the yearbooks were calculated on 
the basis of the rating curve for the profile analysed, which in turn is based on daily water level observations (measured daily at 6.00 UTC) and monthly flow velocity measurements (Pasławski, 1973). The SSC was measured over various time intervals: every fifth day, every second day or daily, depending on the water stage and turbidity, in accordance with the methodology adopted by the State Hydrological and Meteorological Service (Brański, 1968; Pasławski, 1973). Water samples were collected with a slow-filled bathometer bottle (PIHM-1) at one point along the cross section of the river channel at a depth of $1 \mathrm{~m}$, or half this value if the river depth was $<2 \mathrm{~m}$. The SSC was determined in 2 I samples using filters by the direct weight method. The accuracy of the point measurement depends on the SSC at a given point and the volume of the sample taken. According to Brański (1967), when the sample volume is 2 litres and the SSC in the water is $\geq 20 \mathrm{~g} \cdot \mathrm{m}^{-3}$, the measurement error should not exceed $20 \%$. In cases where the SSC is low, e.g., $<10 \mathrm{~g} \cdot \mathrm{m}^{-3}$, the error is permitted to increase to $30 \%$. In "Rocznik Hydrologiczny wód powierzchniowych" SSC data are published as estimates of daily average values in the river cross-section.

The 20-year series of annual means was evaluated using the non-parametric Mann-Kendall trend test, Seasonal Sen's slope and Pettitt's test for change point detection (Kundzewicz and Robson, 2004; Machiwal and Jha, 2012) to determine long-term changes in SSC and discharge. If the Pettitt test indicated significant abrupt changes, the time series were divided into subperiods and a gradual trend analysis was performed. To determine the correlation between SSC and other parameters, Kendall's $\tau$ test was used with the measured values only, however, for time series analysis, the data were interpolated linearly to obtain daily values. To analyse the seasonal pattern of SSC and discharge, daily series were smoothed using a monthly moving average.

Based on the measured daily SSC values, the total load of suspended sediment (SSL) carried by the river during a year through each cross-section were estimated using the following equation:

$$
\mathrm{SSL}=10^{-6} \sum_{i=1}^{d}\left(Q_{i} \cdot \mathrm{SSC}_{i} \cdot T\right)
$$

where: SSL is the annual suspended sediment load ( $t)$, is the daily discharge $\left(\mathrm{m}^{3} \cdot \mathrm{s}^{-1}\right)$, is the daily mean suspended sediment concentration $\left(\mathrm{g} \cdot \mathrm{m}^{-3}\right)$, is length of the day in seconds (s) and $d$ is the number of days in the year.

Where no data existed for a day, interpolated data were used. This approximation can lead to under- or overestimation of SSL if long gaps are present in the time series, as was the case in November-December 1969 (hydrological year), and February 1979 in Gorzów Wlkp. Additional uncertainty arises because daily SSC values are based on point measurements instead of on whole-river cross-section examination. This usually leads to underestimation of real SSL values (Michalec, 2009).

Dependence of cumulative suspended sediment load versus cumulative discharge, i.e. the double-mass curve, was used to analyse changes in sediment transport at each gauge station (Searcy and Hardison, 1960; Walling and Fang, 2003). Significant changes in the slope of the linear relationship was detected by the Davies test, then segmented regression was applied. All statistics were computed with R software (R Core Team, 2013; Pohlert, 2020).

\section{RESULTS}

\section{SSC AND DISCHARGE VARIABILITY ALONG THE RIVER COURSE DURING THE PERIOD 1961-1980}

The gauge stations investigated are located at the upper, middle and lower sections of the river course, and they differ significantly in discharge value. The mean discharge calculated for the two decades is $52 \mathrm{~m}^{3} \cdot \mathrm{s}^{-1}$ at Sieradz, $117 \mathrm{~m}^{3} \cdot \mathrm{s}^{-1}$ at Poznań and $237 \mathrm{~m}^{3} \cdot \mathrm{s}^{-1}$ at Gorzów Wlkp. (Table 1). These values increase downstream, in contrast to changes in the SSC. Over the course of the period studied, the SSC were the highest and demonstrated the highest variability in the upstream section of the river (mean and maximum SSC at Sieradz: 33.7 and $612 \mathrm{~g} \cdot \mathrm{m}^{-3}$, respectively); these values gradually decreased moving downstream (mean and maximum SSC being respectively 22.3 and $414 \mathrm{~g} \cdot \mathrm{m}^{-3}$ at Poznań and 14.5 and $80 \mathrm{~g} \cdot \mathrm{m}^{-3}$ at Gorzów Wlkp.; Table 1).

The most frequent events are characterized by SSC scores below mean values, and hence are better described by median values. This is clearly visible in Figure 2 , which shows the proportion of days in each hydrological year characterized by five levels of SSC, i.e. $0-20,20-40,40-60,60-80$ and $>80 \mathrm{~g} \cdot \mathrm{m}^{-3}$. Those with $<20 \mathrm{~g} \cdot \mathrm{m}^{-3}$ dominate in the period investigated at all stations, and their percentage increases downstream. Across in the whole 20-year period, this SSC class was observed for $\sim 60 \%$ of all days at Sieradz, $65 \%$ at Poznań and $76 \%$ at Gorzów Wlkp. At the last station, these low SSC values can be observed throughout the year in a couple of cases (e.g., 1962, 1963; Fig. 2). However, the percentage of values between 20 and $40 \mathrm{~g} \cdot \mathrm{m}^{-3}$ decreases over time, and SSC values $>40 \mathrm{~g} \cdot \mathrm{m}^{-3}$ become much more common after 1973. Before this time, such events appeared only sporadically. The highest category of SSC $\left(>80 \mathrm{~g} \cdot \mathrm{m}^{-3}\right)$ was originally prevalent only at Sieradz, where it was observed for over half a year in 1975 and for almost half a year in 1980. At Gorzów Wlkp., no such high SSC values were reported, and even SSC values $>60 \mathrm{~g} \cdot \mathrm{m}^{-3}$ were only observed rarely (Fig. 2).

All readings taken since 1974 indicate that the annual mean SSC values gradually decrease downstream (Appendix 2). However, before this time, the differences between all three stations were less pronounced, and the highest annual mean SSC was observed equally frequently at the Sieradz and Poznań gauge stations. The highest annual SSC means were observed at different locations in different years. At Sieradz, the highest mean SSC values $\left(>90 \mathrm{~g} \cdot \mathrm{m}^{-3}\right)$ were obtained in 1975 and 1980, at Poznań in 1969, 1973 and $1974\left(>40 \mathrm{~g} \cdot \mathrm{m}^{-3}\right)$, and at Gorzów Wlkp. in $1974\left(29 \mathrm{~g} \cdot \mathrm{m}^{-3}\right)$ (Appendix 2). Such variation suggests that events characterized by high SSC values may be associated with local influxes of suspended solids.

Significant abrupt changes in SSC can be clearly seen at all stations over the course of the 20-year period, and it is possible for the period to be divided into two subperiods (Fig. 3 and Table 2). The SSC remains relatively low in the initial period, but increases rapidly and becomes more variable later on. According to Pettitt's Change-point Detection Test, this second period begins the earliest at Gorzów Wlkp. (since 1968), followed by Poznań (1969) and then Sieradz (1973), however, an isolated example of very high SSC was also observed at Sieradz in 1969 (January-February). Mean SSC changed between these subperiods by a factor of $\sim 2$ at Gorzów Wlkp. (from 9 to $18 \mathrm{~g}$. $\mathrm{m}^{-3}$ ) and Poznań (from $13 \mathrm{to} 29 \mathrm{~g} \cdot \mathrm{m}^{-3}$ ), and by $\sim 3.5$ at Sieradz 
Basic characteristics of the Warta River and its catchment, as well as hydrological parameters at three gauge stations: selected statistics of discharge (Q) and suspended sediment concentration (SSC) calculated on the basis of data measured for the period 1961-1980; in the case of maximum SSC values, the date of their occurrence is also provided

\begin{tabular}{|c|c|c|c|}
\hline Gauge station & $\begin{array}{l}\text { Sieradz } \\
\text { Upstream }\end{array}$ & $\begin{array}{c}\text { Poznań } \\
\text { Middle-stream }\end{array}$ & $\begin{array}{l}\text { Gorzów WIkp. } \\
\text { Downstream }\end{array}$ \\
\hline Distance from the mouth [km] & 521 & 242 & 56 \\
\hline Slope of the catchment [\%o] & 3.65 & 1.68 & 1.29 \\
\hline Average gradient of the river [\%o] & 0.88 & 0.27 & 0.18 \\
\hline $\begin{array}{c}\text { Discharge } \mathrm{Q}\left[\mathrm{m}^{3} \cdot \mathrm{s}^{-1}\right]: \\
\text { mean/median } \\
\text { (quartiles } 25 \div 75 \% \text { ) }\end{array}$ & $\frac{51.0 / 42.6}{(32.7 \div 58.7)}$ & $\frac{114.3 / 90.5}{(60.5 \div 141.0)}$ & $\frac{232.9 / 197.0}{(145.0 \div 284.0)}$ \\
\hline $\begin{array}{l}\text { SSC }\left[\mathrm{g} \cdot \mathrm{m}^{-3}\right] \\
\qquad \frac{\text { mean / median }}{\text { (quartiles } 25 \div 75 \%)}\end{array}$ & $\frac{33.7 / 16.0}{(9.5 \div 34.4)}$ & $\frac{22.3 / 16.0}{(10.0 \div 25.5)}$ & $\frac{14.5 / 12.0}{(8.0 \div 20.0)}$ \\
\hline $\max \mathrm{SSC}\left[\mathrm{g} \cdot \mathrm{m}^{-3}\right]$ & $\begin{array}{c}612 \\
\text { (February, 1969) }\end{array}$ & $\begin{array}{c}414 \\
\text { (September, 1969) }\end{array}$ & $\begin{array}{c}80 \\
\text { (November, 1967) }\end{array}$ \\
\hline
\end{tabular}
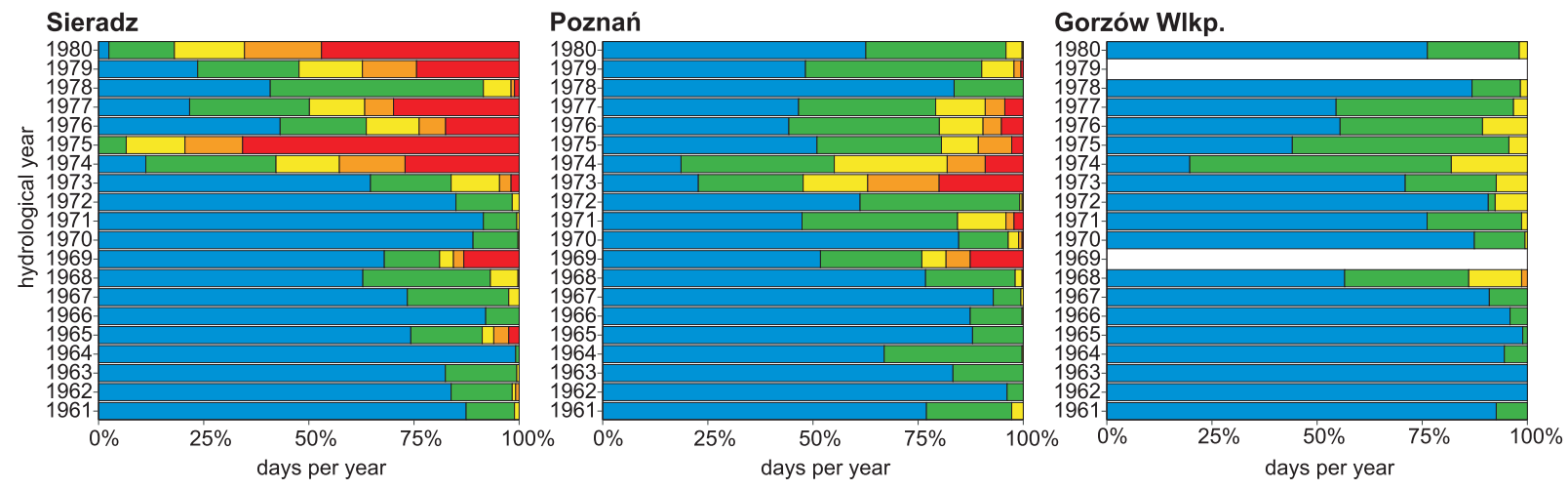

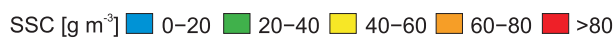

Fig. 2. The frequency of defined concentration classes of suspended sediment occurrence during a single hydrological year over the period 1961-1980 at three gauge stations investigated on the Warta River

The figures are based on IMGW-PIB data, linearly interpolated to daily data, except for hydrological years 1969 and 1979 at Gorzów WIkp. due to lack of data for XI-XII or II, respectively

(from 17 to $59 \mathrm{~g} \cdot \mathrm{m}^{-3}$; Fig. 3). The Mann-Kendall test did not identify any significant gradual trends during the subperiods (Table 2); in addition, neither abrupt change nor gradual trends were detected at Gorzów Wlkp. or Poznań when discharge was taken into account. At Sieradz, a significant trend can be seen over the 20-year study period (Mann-Kendall $\tau=0.4, p=0.015$ ) with a slope $0.93 \mathrm{~m}^{3} \cdot \mathrm{s}^{-1}$ per year.

\section{DISCHARGE VERSUS SSC}

No clear pattern was observed regarding the annual variation of both SSC and discharge (Fig. 4). Although maximum discharge usually occurs between January and April, it can shift both to winter or summer months, and additional peaks of very high discharge can be observed throughout the year. The an- nual SSC profiles appear to demonstrate the greatest variation at Sieradz and Poznań, with the highest SSC events being observed throughout the year, lasting from several weeks to several months. At Gorzów Wlkp., peaks of SSC usually occur in the summer months (May-July) but some variation is observed. However, no coincidence is observed between peak maximum SSC and discharge level.

Different relationships between SSC and discharge can be observed for each year and at each gauge station. Generally speaking, only a very weak relationship can be seen over the entire period studied, both for daily (Kendall $\tau$ in the range of -0.16 to 0.08 ) and monthly readings ( $\tau-0.10$ to 0.11 ) (Fig. $5 \mathrm{~A}$ and Appendix 3), with stronger negative correlations being observed for the daily data during some years. This was particularly true at the Poznań and Gorzów Wlkp. stations, where high SSC values often coincide with low discharge, and low SSC 

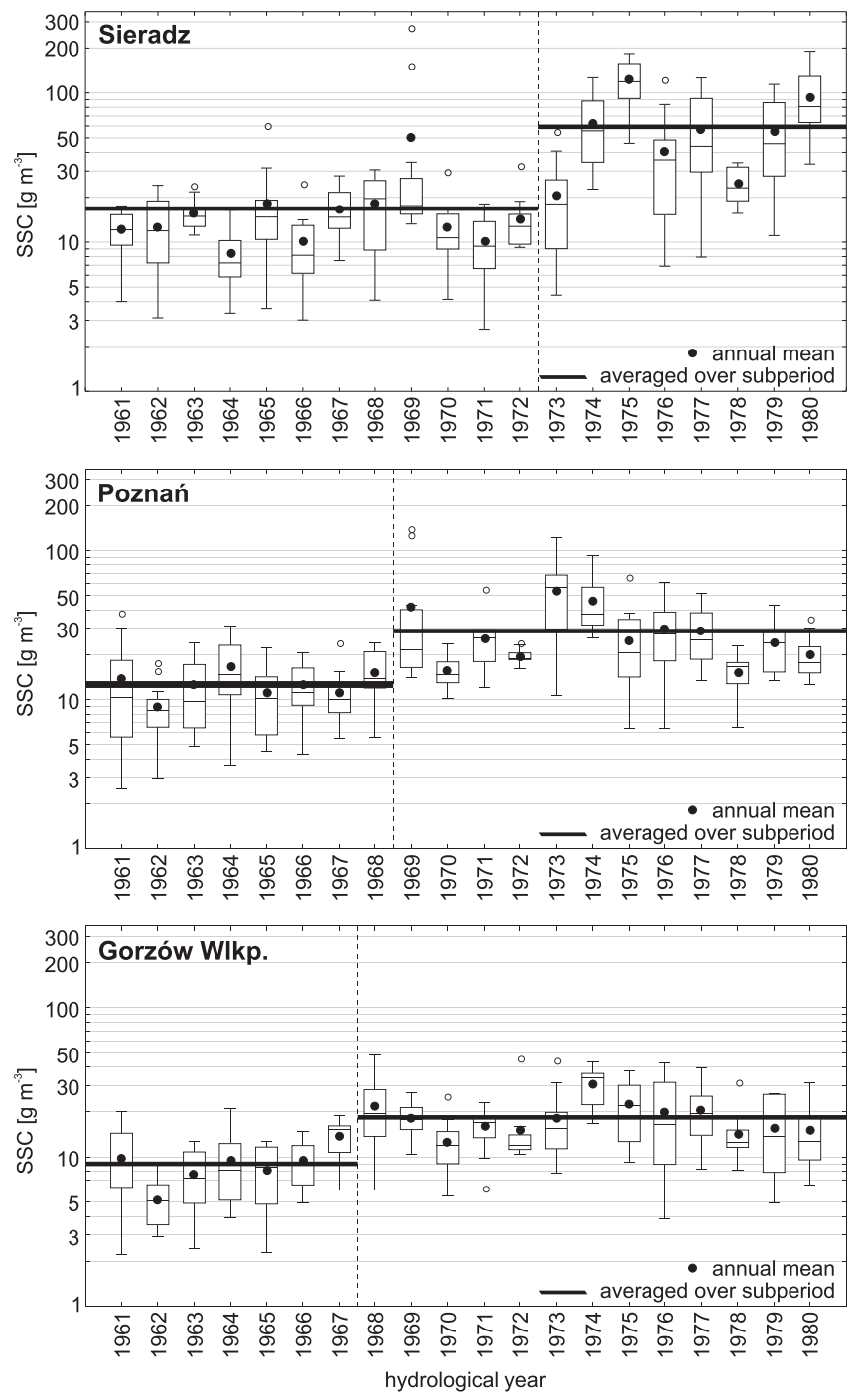

statistics of monthly means:

- median $\square$ range of quartiles $\mid$ non-outlier range o outliers

Fig. 3. Fluctuations of annual (•) means and statistical analysis of monthly mean SSC values in hydrological years, over the period 1961-1980 at three gauge stations

Dashed lines indicate points of abrupt change as detected by Pettitt's test, black lines indicate mean SSC in subperiods (logarithmic scales of vertical axes)

with increasing discharge. This relationship can be seen clearly in 1979 at Sieradz, but is also visible in 1975 and 1968 at Gorzów Wlkp. and throughout the entire period recorded at Poznań, being most evident in 1975 and 1968 (Fig. 5B and Appendix 3).

Significant positive correlations between SSC and discharge can be observed only very rarely and they tend to be very weak (maximum Kendall $\tau=0.26$ in 1965 at Gorzów Wlkp). In addition, the analysis of the periods of high-water stage, during early spring or summer, does not reveal any regular influence of discharge on SSC. For example, SSC was found to remain low in 1963 (Fig. 6), and in other years when flood events occurred, however, the opposite relationship can be seen dur- ing low-water stages in 1963 and during some other years: SSC was found to be relatively high during the summer-autumn lower water stages. During those periods, SSC may reach maximum values for the entire hydrogeological year (Figs. 4 and 6). However, even if the maximum SSC occurs in winter or early spring rather than summer, an overall positive correlation can be observed between SSC and temperature ( $\tau$ up to 0.52 ): a clear increase in annual SSC with water temperature in the summer months, and a decrease in SSC and water temperature in early autumn (Fig. 4). Such trends were observed most often at Gorzów Wlkp. (Appendix 3), however, the exact relationship between SSC and water temperature varies according to year, season and location.

\section{SSL VARIABILITY ALONG THE RIVER'S COURSE DURING THE PERIOD 1961-1980}

Our findings indicate that the SSL increases downstream (Fig. 7 and Appendix 4). Taking into account that the SSC decreases downstream (Table 1 and Fig. 2), we conclude that this increase in SSL is caused mainly by the increasing discharge observed downstream (Table 1). During the period 1961-1980, the Warta carried annually on average 58,000 tonnes of suspended sediments at Sieradz, 73,700 tonnes at Poznań and 108,200 tonnes at Gorzów Wlkp. (Appendix 4). However, those values varied during the study period (Fig. 7 and Appendix 4). There were years when the SSL values were the highest at the upstream or middle-stream gauge stations. For example, in 1975 and 1980, the highest SSL values were reported at Sieradz, whereas in 1973, the highest SSL values were reported at Poznań. Those years were characterized by discharge values close to mean values (Fig. 7), but high SSC values were also observed (Fig. 3). More exceptions to the rule that SSL increases downstream were observed when monthly means were taken into account, suggesting that such changes are influenced principally by local factors, such as incidental anthropogenic increases in SSC, changes in discharge during snowmelt or the occurrence of ice phenomena. Incidences of increased suspended sediment supply at a particular station cannot be observed at those downstream, implying that the suspended sediments must be deposited along the river course.

During the 20-year-period analysed, no gradual trends in discharge were detected, except at Sieradz (Table 2); this suggests that long-term changes of SSL (Fig. 7) at each gauge station are determined mainly by the temporal pattern of SSC values and their abrupt changes (Fig. 3). At Sieradz, SSC and SSL both increased after 1972, although the latter remained at relatively low levels, as indicated by the breakpoint of the double-mass plot of SSL vs. discharge, as detected by the Davis test. Although SSL remained relatively low in 1973, due to the decreased discharge level, thus extending the initial "low" period by one year, a clear increase in the slope of the double mass curve could be observed in 1974 (Fig. 7).

At Poznań, changes in the relationship between cumulative SSL and discharge were observed in 1969, along with an abrupt change in SSC, however, from 1978, SSL was observed to decrease, as indicated by the second significant breakpoint of the double-mass curve, and SSC slightly decrease (Fig. 3). At Gorzów, a significant change in SSL has been observed since 1967, mainly due to an associated increase in discharge levels (Fig. 7). The annual mean SSC level in 1967 was also relatively high, however, a previous analysis reported that the sharp change in SSC only occurred from 1968 (Fig. 3). During the first subperiod, i.e. before this sharp change, suspended 
Results of long-term trend analysis of SSC and discharge annual mean time series (data in bold are significant at $p<0.05$ )

\begin{tabular}{|c|c|c|c|c|c|c|c|}
\hline \multirow{2}{*}{ parameter } & \multirow{2}{*}{ location } & \multirow{2}{*}{$\begin{array}{c}\text { Pettitt test } \\
\text { p-value }\end{array}$} & \multicolumn{5}{|c|}{ Mann-Kendall test and Sens Slope } \\
\hline & & & Change & period & p-value & $\tau$ & slope \\
\hline \multirow{6}{*}{ SSC } & \multirow{2}{*}{ Sieradz } & \multirow{2}{*}{0.006} & \multirow{2}{*}{1972} & $1961-1972$ & 0.537 & 0.15 & 0.27 \\
\hline & & & & 1973-1980 & 0.710 & 0.14 & 4.81 \\
\hline & \multirow{2}{*}{ Poznań } & \multirow{2}{*}{0.005} & \multirow{2}{*}{1968} & 1961-1968 & 0.901 & 0.07 & 0.13 \\
\hline & & & & 1969-1980 & 0.373 & -0.21 & -1.21 \\
\hline & \multirow{2}{*}{$\begin{array}{l}\text { Gorzów } \\
\text { Wlkp. }\end{array}$} & \multirow{2}{*}{0.007} & \multirow{2}{*}{1967} & $1961-1967$ & 0.230 & 0.43 & 1.01 \\
\hline & & & & 1968-1980 & 0.502 & -0.15 & -0.19 \\
\hline \multirow{3}{*}{ Q } & Sieradz & 0.567 & - & $1961-1980$ & 0.015 & 0.40 & 0.93 \\
\hline & Poznań & 0.249 & - & $1961-1980$ & 0.064 & 0.31 & 2.37 \\
\hline & $\begin{array}{l}\text { Gorzów } \\
\text { Wlkp. }\end{array}$ & 0.153 & - & $1961-1980$ & 0.183 & 0.22 & 3.39 \\
\hline
\end{tabular}

sediment was transported at the average rate of 24,400 tonnes per year at Sieradz (1961-1973), 37,800 tonnes per year at Poznań (1961-1968) and 50,900 tonnes per year at Gorzów Wlkp. (1961-1966); hence, downstream, the transport rate at Gorzów Wlkp. was 1.3-times higher than at Poznań, and 1.5-times higher at Poznań than at Sieradz. However, as noted above, this relationship was disturbed by exceptional cases in 1973, 1975 and 1980.

\section{DISCUSSION}

This study shows that the discharge of the Warta River increases and SSC decreases when moving downstream (Fig. 4). In addition, an increase in downstream discharge resulted in an increase in the amount of suspended sediment (SSL). Such conclusions have already been drawn from studies of the longest Polish rivers, the Wisła, Oder and Warta, conducted during the 1940s and 1950s (Jarocki, 1957; Mikulski, 1961). However, our estimates of the SSL indicates also a general increase in the amount of suspended sediment transported in the Warta during the period studied, 1961-1980 (Fig. 7).

Our findings indicate that long-term changes of SSL at each gauge station were primarily associated with the pattern of SSC changes, with only slight modifications by inter-annual changes of discharge. The highest SSC was $>60 \mathrm{~g} \cdot \mathrm{m}^{-3}$ in the upstream sections of the Warta and $>40 \mathrm{~g} \cdot \mathrm{m}^{-3}$ in downstream sections (Fig. 2); these levels are abnormal and may indicate the occurrence of incidental events, most likely of anthropogenic origin.

Increases in SSC observed at particular time periods are closely correlated with human activities carried out in the Warta River valley. At Sieradz, upstream of the Warta River valley, the river training works began after 1972, included strengthening groynes and deepening the riverbed (according to document TUW.433.2.2016 obtained from the Regional Water Management Authority in Poznań). Furthermore, in 1973, one of the largest lignite mines in Europe, Bełchatów (Fig. 1), was opened, which caused discharge of wastewater to the Widawka River, a right-bank tributary of the Warta near Sieradz (Wachowiak, 1988; Pierzchała, 2010). These activities caused, at Sieradz, an increasing trend in SSC and SSL which clearly accelerated after 1974 (Figs. 4 and 7).

In Poznań, between 1969 and 1974, large-scale river training works were conducted as a part of planned flood protection measures, resulting in the construction of a new riverbed (Lewandowski and Rembeza, 1972; Kaniecki, 2004, 2013; Poznańska Wiki, 2020). This is reflected in the increase of SSC and SSL from 1969. After 1974, the SSC level clearly decreased in the river, but remained higher than the value at the beginning of the 20-year period analysed.

During the second half of the 1960s, such river engineering was works also conducted on a downstream section of the Warta near Gorzów Wlkp. (Goraj, 2015), and from 1967, SSL was found to increase in relation to discharge. The Warta was intensively used as an inland waterway during this period (Klause, 2008), and as such, dredging was often conducted; this undoubtedly had an impact on the river banks and on deep-seated erosion processes.

The results of this research are in line with those of previous studies on suspended sediments in lowland rivers (see Łajczak, 1999, 2003; Siakeua et al., 2004). An analysis of SSC measurements in the Vistula, the longest Polish river, over a 100-year-period,1890-1995, revealed SSC to be significantly greater during the four initial decades, i.e. until around 1930, as a result of river engineering measures (Łajczak, 1999, 2003). After this period, the SSC started to decrease, probably in response to the construction of dams and barrages, river channel stabilisation measures and changes in land use in the river catchment, particularly urban development.

Long-term observations indicate that the changes triggered by natural factors are not rapid, and that the river carries a generally constant amount of suspended sediment. Only the presence of ice cover can induce a rapid increase of SSC. At Sieradz in 1969, the presence of ice cover was found to have a significant influence on SSC and maximum SSC in the period analysed, probably by intensified riverbed erosion as a result of tunnelled flow (see Skolasińska and Nowak, 2018). However, the suspended load quickly returned to the previous low level (Figs. 4 and 7). Moreover, the effect of ice on SSC is mostly incidental as the increase in air and water temperatures contribute to a significant shortening of the period of occurrence of ice phenomena on the river, i.e. by 9.5 days decade ${ }^{-1}$, and the duration of ice cover falling by 5.5 days decade ${ }^{-1}$ (Nowak et al., 2019).

Other important natural factors contributing to the increase in SSC in the Warta may be discharge and water temperature. Al-Anseri et al. (1988) and Asselman (1999) proposed that the positive correlation between discharge and SSC can be attributed to higher river flows being capable of transporting larger masses of suspended sediments, however, no such correlation 

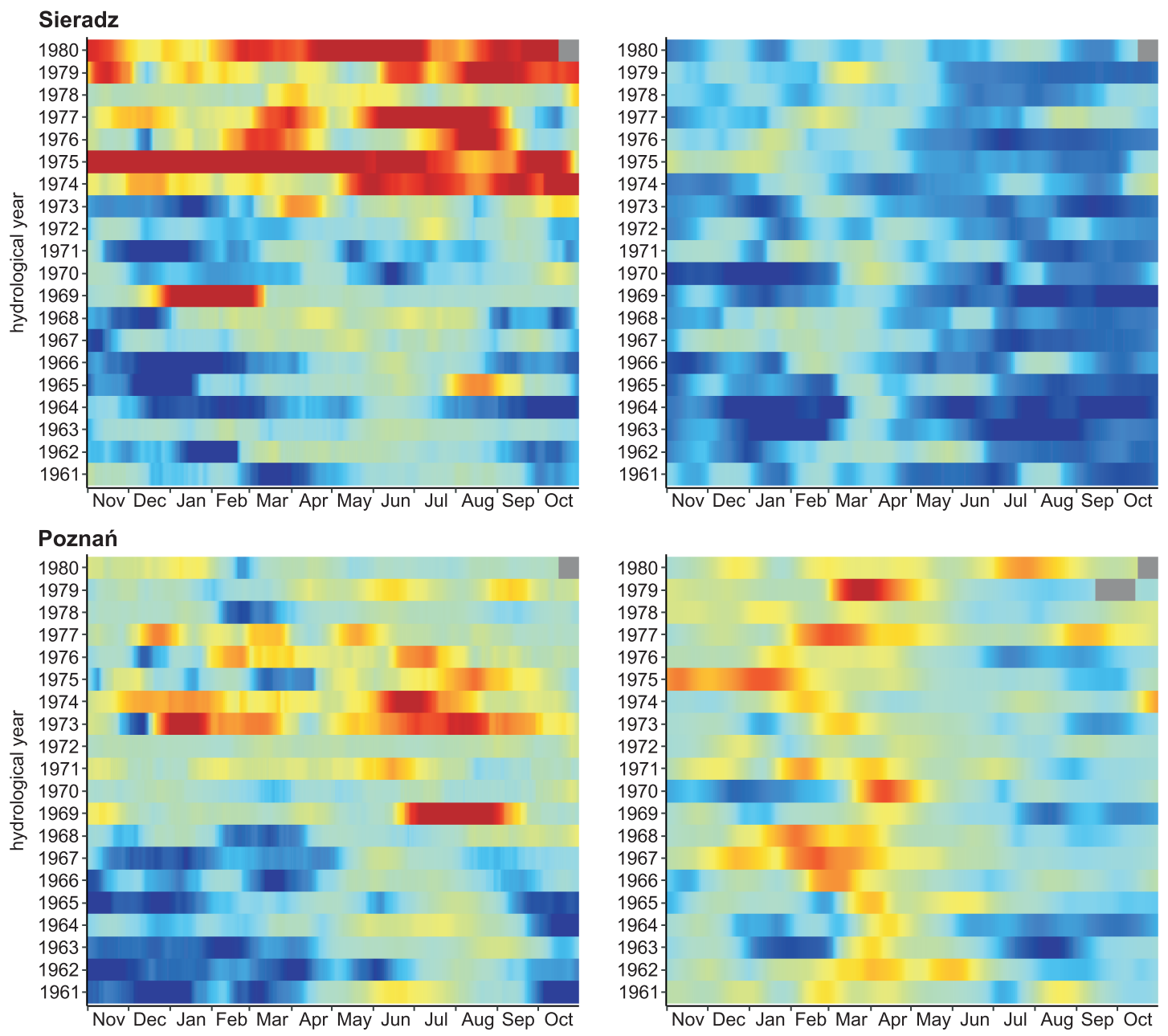

\section{Gorzów Wlkp.}
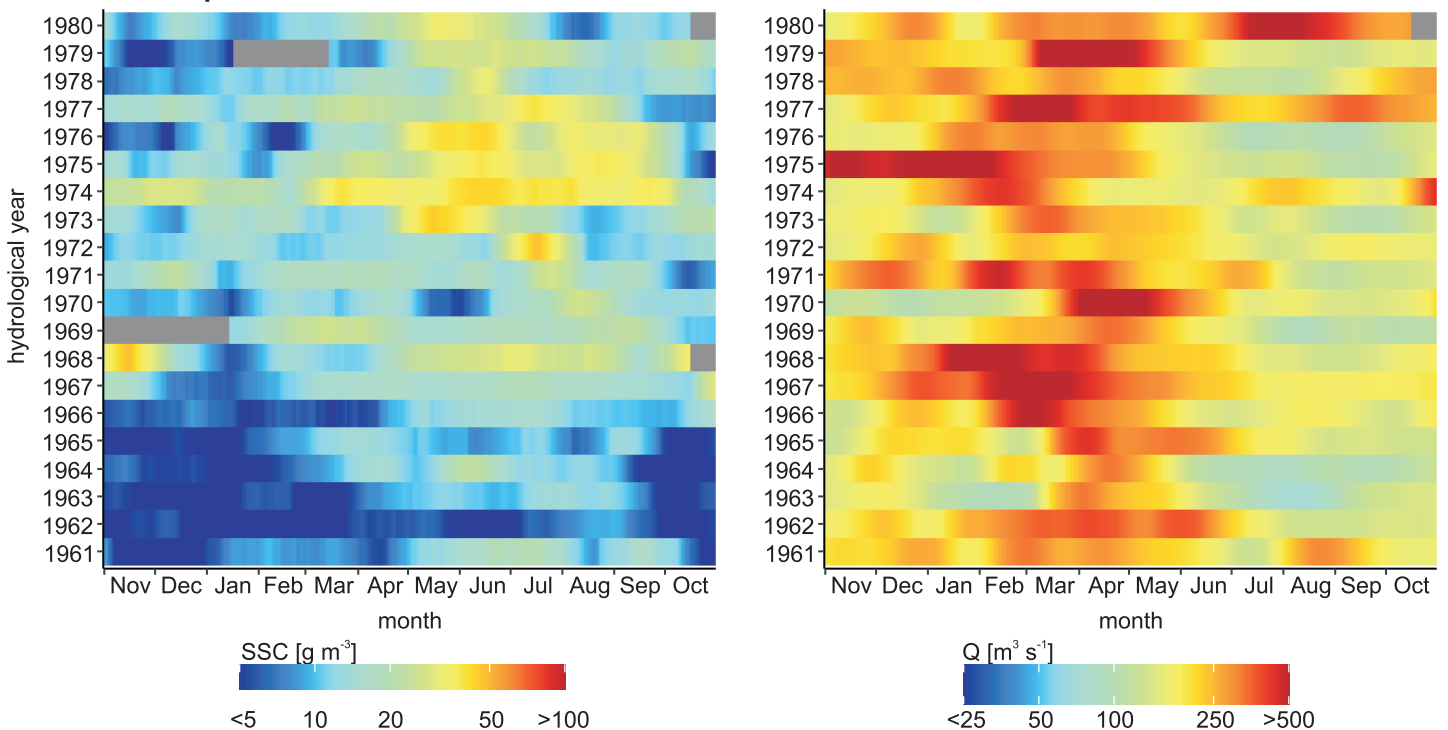

Fig. 4. Interannual variations of seasonal patterns of suspended sediment concentration (SSC) and discharge (Q) (monthly moving average, logarithmic colour scale, grey means no data) 

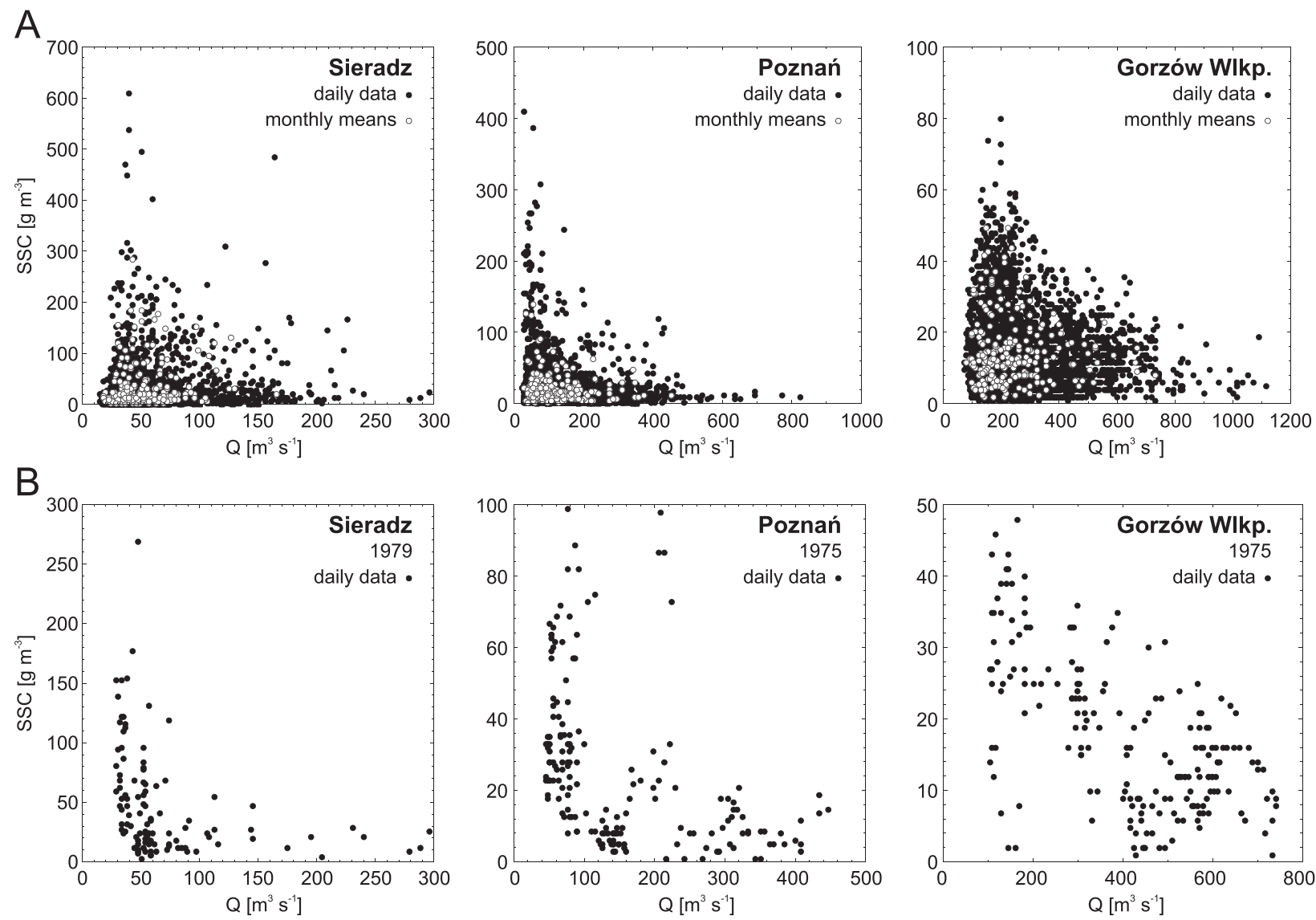

Fig. 5. Scatter plots of suspended sediment concentration (SSC) and discharge (Q)

A - daily data (black circles) and monthly mean data (white diamonds) over the period 1961-1980; B - daily data for the hydrological years chosen showing an inverse relationship between SSC and Q

was observed in the present study, even in the periods before anthropogenic influences were apparent (Appendix 3). The results of this study are consistent with those presented by Wood (1977) and Siakeua et al. (2004), among others, indicating that the SSC values can vary independently of discharge.

Therefore, when determining the causes of SSC variability, discharge should not be taken into consideration as the most significant factor. The growth of phytoplankton may also play a role, as this would promote changes in the concentration of organic matter in suspension. In the present study, the dataset analysed did not include information about the proportion of organic matter in the suspension, or other indicators of phytoplankton development, such as chlorophyll a concentration, however, the fact that high SSC values were observed during the summer period at low discharge and a positive correlation was found between SSC and water temperature suggests that phytoplankton may indeed play a role. Studies of other lowland rivers in Europe (Desortová and Punčochář, 2011; Hillebrand et al., 2018) show similar relationships between SSC, discharge and water temperature and intense growth of phytoplankton in summer. An important factor contributing to the increase in phytoplankton growth in the Warta may be the progressive degradation of water quality observed during the period investigated (Chełmicki, 2012; Górski et al., 2019). As noted earlier, land use outside residential regions is dominated by agriculture.
Water quality fell mainly as an effect of fertilization of arable land, as well as through the uncontrolled discharge of domestic sewage and industrial pollution from growing cities and large industrial plants. The polluted water discharges in the Warta catchment area induce highly eutrophic conditions and favour phytoplankton blooms during summer (Madrecka and Szelag-Wasielewska, 2017; Górski et al., 2019). Such increases in the proportion of organic matter among the solids suspended in rivers may represent one of the negative effects of global warming. The expected increase in air and water temperatures in the coming years will result in more frequent and longer periods of drought, and thus an increase in phytoplankton biomass in rivers. The organic component and biotic processes are rarely included in assessments of river dynamics of suspended sediment loads. As high concentrations of suspended organic matter may worsen the ecological status of rivers, it is imperative to identify the driving forces behind variation in suspended sediment load, and their contributions. Temperature is only one of the factors that controls phytoplankton growth and is not sufficient to explain the variability of organic content in total SSC. Therefore, the present study employed a variety of statistical models (results not included) that examined the effect of discharge $(Q)$, water temperature $(T)$ or days from the previous ice phenomenon on SSC variability. At best, however, they did not explain $>23 \%$ of the SSC variance (linear multiple regression, 

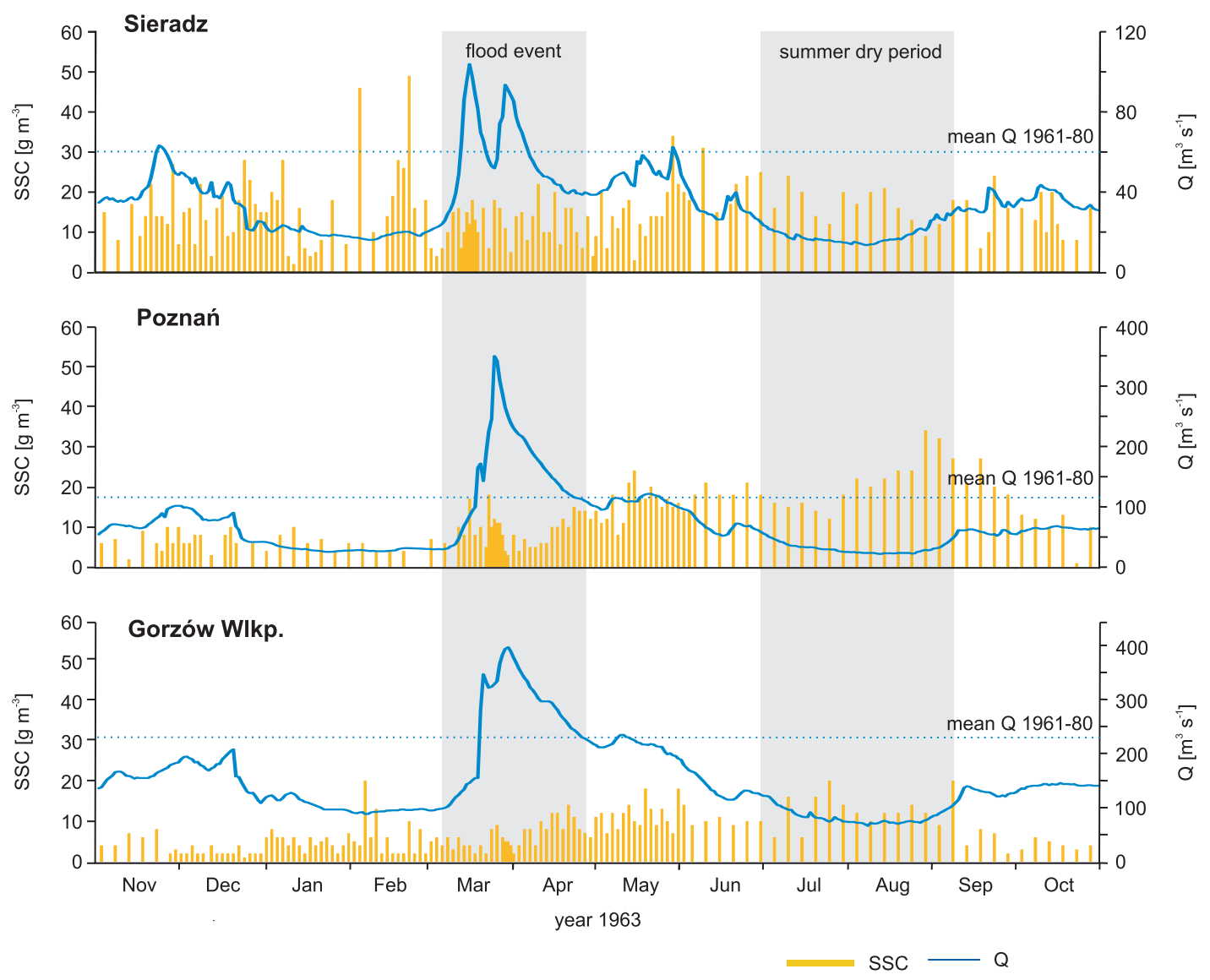

Fig. 6. Suspended sediment concentration (SSC) and discharge (Q) during the year 1963 at the three gauge stations tested with flood events and summer dry periods indicated

Note the different scale on the $Y$ axis $(Q)$

logarithmic training of SSC, for Gorzów Wlkp. in the period 1960-1966).

The SSL is a value from which denudation rate and its fluctuations are determined. The principal assumption behind using the SSL as a realistic proxy of denudation rate is that both the quantity and quality of the suspended sediments measured at a single point (i.e., a gauge station) located downstream of the river course are representative of the denudation processes in the entire catchment area of the river. This reasoning, shared by many researchers (see Jarocki, 1957; Dębski, 1959; Pasławski, 1973; Kostrzewski and Zwoliński, 1990; Brański and Banasik, 1996), seems justified in the case of a river catchment where the presence of suspended sediments in the river is governed only by natural factors, such as fluvial erosion or surface runoff. However, the additional influence of anthropogenic factors, mainly controlling the quantity of the suspended sediments in the river, often biases the assessment of the denudation index calculated on the basis of SSC alone, without any detailed analysis of drivers of its fluctuations (see Kijowska-Strugała, 2015; Skolasińska and Nowak, 2018). In the case investigated of the Warta, where the highest SSC measurements are likely associated with the disposal of wastewater from the open-pit mine at Bełchatów or river training works, it seems unreasonable to suggest that the denudation processes have accelerated (as shown by Brański and Banasik, 1996). Therefore, in any urban and/or industrial areas, a denudation index calculated solely based on SSC measurements, and the resultant interpretations, must be treated with caution.

In addition, it also seems questionable to make any assessment of the denudation rate without performing any qualitative analyses of the suspended sediments, as these provide information regarding the amount of organic matter in the total suspended load. The suspended organic matter content often constitutes a substantial, or even dominant, part of the total suspended load of which the majority is produced in situ in the river water; it is not delivered from the river catchment (e.g., Hillebrand et al., 2018). Hence, it should be excluded from the assessments of denudation rate.

In summary, the present analysis of a large, mostly urbanised lowland river catchment subjected to river training measures found that anthropogenic factors have had a significant impact on its SSC and SSL content over a 20 -year period. Although this period is a short one with regard to the geological time scale, it is nevertheless sufficient to demonstrate clear trends resulting from human influence. The changes recorded are significant ones, indicating the presence of considerable human-induced changes taking place amongst the naturally-occurring processes. 
A
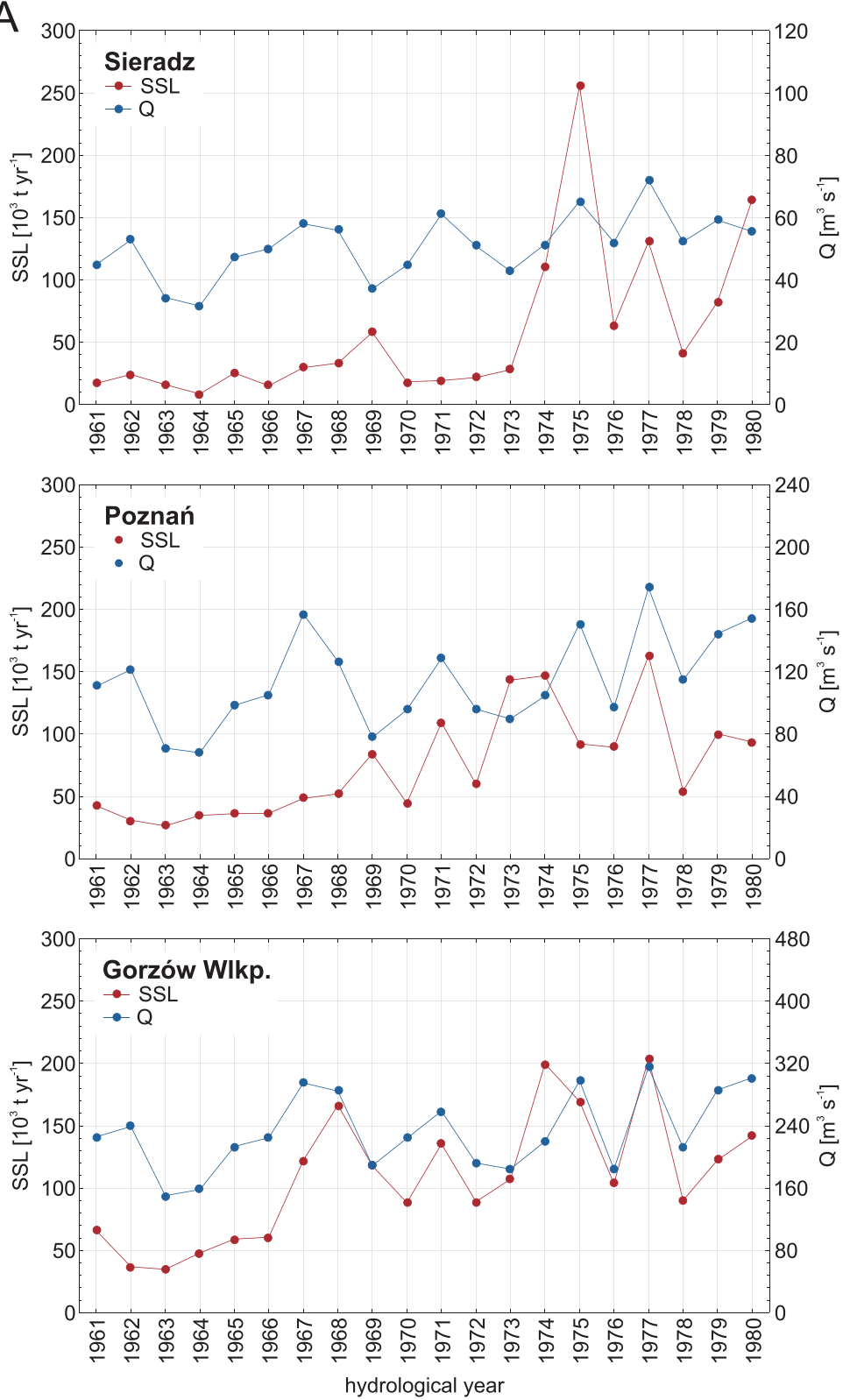

B
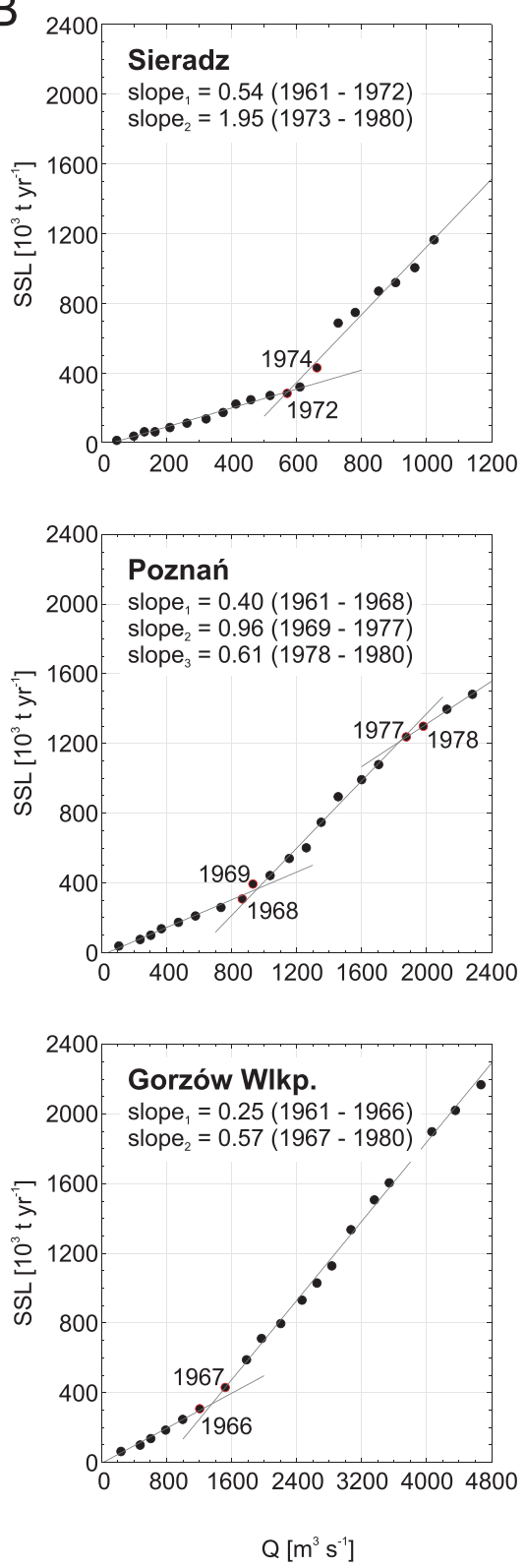

Fig. 7. Changes in the annual mean discharge (Q) and suspended sediment loads (SSL) in the Warta River

A - double-mass plots based on cumulative $Q$ and SSL values; B - years (and time period) characterized by increased SSL during the period analysed, 1961-1980, are marked; note the different scale for the $Q$ axis

\section{CONCLUSIONS}

Based on the results of the dataset analysed, collected during the period 1961-1980 at three gauge stations (Sieradz, Poznań and Gorzów Wlkp.) downstream in the Warta River, the following conclusions can be drawn:

- Downstream, SSC shows a decreasing trend while SSL increases due to an increase in downstream discharge.
- In the lowland river, where many river training works have been undertaken, human activity significantly influences the fluctuations observed in both SSC and SSL; at each gauge station during the 20 -year period analysed, both SSC and SSL show an increasing trend, mainly caused by the river trainings and the disposal of wastewater from mines and industry.

- The highest reported SSC values are of local significance, and no correlation was observed between the sampling sites at the three gauge stations, located $\sim 200 \mathrm{~km}$ apart. 
- No significant correlation was found between discharge and SSC, although during some of the years investigated, a specific relationship appeared to exist: high SSC occurs in summer periods with low discharge, and changes in SSC correlate with seasonal changes of temperature, a trend which is most likely related to the growth of phytoplankton.

- Where the river catchment analysis was greatly affected by anthropogenic factors, the SSC-based assessment of the denudation index does not appear to reflect the actual denudation rate.
Acknowledgements. We are particularly grateful to B. Sternal for providing language help. We wish to thank T. Zieliński for useful comments on the results and for proofreading the article. Comments from anonymous reviewers helped us to improve the manuscript and we gratefully acknowledge their efforts. The data on suspended sediment concentration and discharge were provided by the Institute of Meteorology and Water Management. This research did not receive any specific grants from funding agencies in the public, commercial, or not-for-profit sectors.

\section{REFERENCES}

Al-Ansari, N.A., Asaad, N.M., Walling, D.E., Hussan, S.A., 1988. The suspended sediment discharge of the River Euphrates at Haditha, Iraq. Geografiska Annaler, 70A: 203-213.

Asselman, N.E.M., 1999. Suspended sediment dynamics in a large drainage basin: the River Rhine. Hydrological Processes, 13: $1437-1450$

Bartkowski, T., 1957. Die Entwicklung des postglazialen Entwässergungssystem im mittleren Grosspolen. Zeszyty Naukowe UAM Poznań, Geografia, 1: 3-79.

Brański, J., 1967. Accuracy of the point measurements of the water turbidity (in Polish and English summary). Wiadomości Służby Hydrologicznej i Meteorologicznej, 3: 19-30.

Brański, J., 1968. Determination of suspended load by direct weight method using filters (in Polish with English summary). Prace PIHM, 94: 13-21.

Brański, J., Banasik, K., 1996. Sediment yields and denudation rates in Poland. The International Association of Hydrological Sciences Publication, 236: 133-138.

Chełmicki, W., 2012. Woda - zasoby, degradacja, ochrona (in Polish). PWN, Warszawa.

Desortová, B., Punčocháŕ, P., 2011. Variability of phytoplankton biomass in a lowland river: response to climate conditions. Limnologica, 41: 160-166.

Dębski, K., 1957. Próba oszacowania denudacji na obszarze Polski (in Polish). Prace i Studia Komitetu Gospodarki Wodnej PAN, 1: 477-481.

Dynowska, I., 1972. Typy reżimów rzecznych w Polsce (in Polish). Zeszyty Naukowe Uniwersytetu Jagiellońskiego, 50.

Falkowski, E., 1975. Variability of channel processes of lowland rivers in Poland and changes of the valley floors during the Holocene. Biuletyn Geologiczny, 19: 45-78.

Forysiak, J., 2010. The application of aerial photo analysis to reconstruct anabranching system of middle part of the Warta river valley (in Polish with English summary). Landform Analysis, 13: 13-18.

Goraj, M., 2015. Evolution of the lower valley Warta of XVII to XX century on the analysis based on cartographic (in Polish with English summary). Dissertations of Cultural Landscape Commission, 28: 99-120.

Górski, J., Dragon, K., Kaczmarek, P.M.J., 2019. Nitrate pollution in the Warta River (Poland) between 1958 and 2016: trends and causes. Environmental Science and Pollution Research, 26: 2038-2046.

Hillebrand, G., Hardenbicker, P., Fischer, H., Otto, W., Vollmer, S., 2018. Dynamics of total suspended matter and phytoplankton loads in the river Elbe. Journal of Soils Sediments, 18: 3104-3113.

Jarocki, W., 1957. Ruch rumowiska w ciekach; badanie oraz obliczanie ilości materiału wleczonego i unoszonego (in Polish). Wyd. Morskie, Gdynia.
Kaniecki, A., 2004. Poznań. The History of the City Written with Water (in Polish with English summary). Wyd. PTPN, Poznań.

Kaniecki, A., 2013. Environmental changes in the Warta valley within the Poznań area connected with antropopressure (in Polish with English summary). Landform Analysis, 24: 23-34.

Kijowska-Strugała, M., 2015. Transport of suspended sediment in the Bystrzanka stream (Polish Flysch Carpathians) under changing antropopressure (in Polish with English summary). Geographical Studies, 247.

Klause, G., 2008. Rivers in Poznań - advantages for recreation and tourism or problems? (in Polish with English summary). Science Nature Technologies, 2: 10.

Kostrzewski, A., Zwoliński, Z., 1990. Denudacja chemiczna i mechaniczna w zlewni górnej Parsęty w roku hydrologicznym 1986 (in Polish). Dokumentacja Geograficzna PAN, 1: 13-30.

Kozarski, S., 1991. Warta - a case study of lowland river. In: Template Paleohydrology (eds. L. Starkel, K.J. Gregory and J.B. and Thornes): 189-215. John Wiley and Sons, Chichester.

Kozarski, S., Rotnicki, K., 1978. Problems concerning the development of valley floors during Late-Würm and Holocene in the Polish Lowland (in Polish with English summary). PTPN, Prace Komisji Geograficzno-Geologicznej, 19: 1-57.

Kundzewicz, Z.W., Robson, A.R., 2004. Change detection in hydrological records - a review of the methodology. Hydrological Science Journal, 49: 7-19.

Lewandowski, J.B., Rembeza, L., 1972. Analysis of changes of the Warta River course within the Poznań city borders based on historical sources (in Polish with English summary). Badania Fizjograficzne nad Polską Zachodnią, 25, seria A, Geografia Fizyczna: 93-112.

Łajczak, A., 1999. Contemporary transport and sedimentation of the suspended material in the Vistula River and its main tributaries (in Polish with English summary). Monografie Komitetu Gospodarki Wodnej PAN, 15.

Łajczak, A., 2003. Contemporary transport of suspended material and its deposition in the Vistula River, Poland. Hydrobiologia, 494: 43-49.

Machiwal, D., Jha, M.K., 2012. Hydrologic Time Series Analysis: Theory and Practice. Springer, Berlin and Capital Publishing Company, New Delhi, India

Mądrecka, B., Szeląg-Wasielewska, E., 2017. Mass development of phytoplankton in the River Warta in Poznań (Poland) in the 21st century. Limnological Review, 17: 79-88.

Michalec, B., 2009. Selected methods for suspended sediment transport determination (in Polish with English summary). Infrastructure and Ecology of Rural Areas. Monograph series, 8.

Mikulski, Z., 1961. Transport zawiesiny mineralnej w rzekach polskich (in Polish). Gospodarka Wodna, 10: 461-463. 
Nelson, E.J., Booth, D.B., 2002. Sediment sources in an urbanizing, mixed land-use watershed. Journal of Hydrology, 264: 51-68.

Nowak, B., Skolasińska, K., Stanek, P., 2019. Zmiany warunków termicznych i lodowych rzeki Warty w Sieradzu w wieloleciu 1956-2014 (in Polish). Varia. Prace z zakresu geografii i geologii. Bogucki Wyd. Naukowe.

Olive, L.J., Rieger, W.A., 1992. Stream suspended sediment transport monitoring - why, how and what is being measured? The International Association of Hydrological Sciences Publication, 210: 245-254.

Pasławski, Z., 1973. Metody hydrometrii rzecznej (in Polish). Wydawnictwa Komunikacji i Łączności, Warszawa.

Parker, R.S., 1988. Uncertainties in defining the suspended sediment budget for large drainage basin. The International Association of Hydrological Sciences Publication, 174: 523-532.

Peng, T., Tian, H., Singh, V.P., Chen, M., Liu, J., Ma, H., Wang, J., 2020. Quantitative assessment of drivers of sediment load reduction in the Yangtze River basin, China. Journal of Hydrology, 580 (in press).

Piechowiak, K. ed., 2007. Charakterystyka regionu wodnego Warty i identyfikacja istotnych problemów gospodarki wodnej (in Polish). MJ Druk, Poznań.

Pierzchała, K. ed., 2010. XXXV-lecie eksploatacji systemu odwodnienia w KWB Bełchatów (in Polish). Materiały Konferencyjne, Bełchatów, 3.09.2010.

Pohlert, T., 2020. Package 'trend': Non-Parametric Trend Tests and Change-Point Detection. R package version 1.1.2.

Poznańska Wiki. Rzeka Warta/Historia [Online]. Available at: https://poznan.wikia.org/wiki/Rzeka_Warta/Historia

Ptak, M., Sojka, M., Kałuża, T., Choiński, A., Nowak, B., 2019. Long-term water temperature trends of the Warta River in the years 1960-2009. Ecohydrology and Hydrobiology, 19: 441-451.

R Core Team, 2013. R: A language and environment for statistical computing. R Foundation for Statistical computing, Vienna, Austria. URL: http://www.R-project.org

Rocznik Hydrologiczny wód powierzchniowych - dorzecze Odry i rzeki Przymorza miedzy Odra i Wisła (1961-1980 - twenty volumes) (in Polish). Państwowy Instytut Hydrologiczno-Meteorologiczny. Wydawnictwa Komunikacji i Łączności, Warszawa
Searcy, J.K., Hardison, C.H., 1960. Double-mass curves. Manual of Hydrology: Part 1. General Surface-Water Techniques. U.S. Geological Survey Water-Supply Paper, 1541-B.

Siakeua, J., Oguchib, T., Aokic, T., Esakid, Y., Jarviee, H.P., 2004. Change in riverine suspended sediment concentration in central Japan in response to late 20th century human activities. Catena, 55: 231-254.

Sinha, R., Eldho, T., Subimal, G., 2020. Assessing the impacts of land cover and climate on runoff and sediment yield of a river basin. Hydrological Sciences Journal, 65: 2097-2115.

Skolasińska, K., Nowak, B., 2018. What factors affect suspended sediment concentrations in rivers?: a study of the upper Warta River (Central Poland). River Research and Applications, 34: 112-123.

Szalińska, E., Orlińska-Woźniak, P., Wilk, P., 2020. Sediment load variability in response to climate and land use changes in a Carpathian catchment (Raba River, Poland). Journal of Soils and Sediments, 20: 2641-2652.

Vercruysse, K., Grabowski, R.C., Rickson, R.J., 2017. Suspended sediment transport dynamics in rivers: Multi-scale drivers of temporal variation. Earth-Science Reviews, 166: 38-52.

Wachowiak, G., 1988. Wpływ zrzutów wód kopalnianych KWB "Bełchatów" na przepływy i temperaturę Widawki (in Polish). Gospodarka Wodna, 5: 102-106.

Walling, D.E., 2008. The changing sediment loads of the world's rivers. Annual of Warsaw University of Life Sciences, Land Reclamations, 39: 3-20.

Walling, D.E., Fang, D., 2003. Recent trend in the suspended sediment loads of the world's river. Global and Planetary Change, 39: 111-126.

Walling, D.E., Webb, B.W., 1981. The reliability of suspended sediment load data. The International Association of Hydrological Sciences Publication, 133: 177-194.

Walling, D.E., Webb, B.W., 1996. Erosion and sediment yield: a global overview. The International Association of Hydrological Sciences Publication, 236: 3-19.

Wood, P.A., 1977. Controls of variation in suspended sediment concentration in the River Rother, West Sussex, England. Sedimentology, 24: 437-445. 